\title{
Журнал «Пороги» (Аргентина): історія, зміст, автори
}

\section{Сергій Козак,} здобувач

Київський національний університет культури і мистецтв

вул. Є. Коновальця, 36, 01601, Київ, Україна e-mail:serkozak@bigmir.net

(C) Козак С., 2018

У статті на основі результатів уперше підготовлених в історії української журналістики хронологічного та систематичного покажчиків змісту - досліджено історію видавання, імена авторів, склад літературних співробітників, тематично-жанрову класифікацію матеріалів журналу «Пороги» - цього унікального історико-літературного документа, який виходив у світ у Південній Америці (1949-1957; Буенос-Айрес, Аргентина).

Ключові слова: «Пороги», журнал, автори, періодичне видання, видавництво.

\section{Постановка проблеми}

У масиві українських еміграційних газет і журналів особливе місце належить літературно-мистецькому часопису «Пороги» (на жаль, у нас малознаному), який у повоєнні роки виходив в Аргентині. Не маючи жодної державної підтримки, журнал майже десятиріччя знайомив своїх читачів з новинками красного письменства, тримав їхній громадянський «тонус» на належній висоті. Саме тому знайомство зі змістом цього видання, по-перше, подарує нам прекрасне відкриття незнаного слова й світу, віддаленого тисячами кілометрів від України, й справжню естетичну насолоду від інформації про твори, не покраяні совєтською цензурою, а, по-друге, надасть можливість для подальшого поглибленого вивчення цього «представника» періодики українського закордоння [1]. Мало того: поруч із «Порогами» маємо ще десятки й десятки періодичних видань, як громадсько-політичних, так і літературно-мистецьких, які досі відомі нам переважно лише за назвами, а не за змістом чи фактами їхньої історії, іменами авторів тощо [2]. Ось чому кожен крок назустріч дослідженню того чи іншого видання є вкрай важливим і наближає нас до розгадки цього, ще не пізнаного нами, феномену - існування української періодики поза межами України. 
Аналіз останніх публікацій

Варто зауважити, що за останні два десятиліття увага дослідників до періодичних видань української еміграції (діаспори) відчутно зросла. Цьому є пояснення: науковців приваблює, по-перше, вже сам, досить значний, масив цих видань (більшість яких, нагадаємо, залишаються недослідженими); по-друге, зацікавлює й так званий «географічний чинник», адже існування еміграційної (діаспорної) періодики пов’язане з десятками міст із багатьох країн світу (Австралія, Австрія, Англія, Аргентина, Бразилія, Канада, Німеччина, США, Франція тощо); по-третє, привабливим $є$ й розмаїте жанрово-тематичне спрямування видань (серед них громадсько-політичні, літературні, гумористичні, спортивні, студентські часописи). Відтак на мапі «наукової діаспоряни» помітними стали, зокрема, такі дослідження: про журнал «ризуб» (дисертація Аліни Тимошик-Сударикової), газету «Український голос» (дисертація Оксани Дзвінчук) [3; 4; 5], журнал «Дукля» (дисертація Оксани Кушнір) [3] тощо. Втім, ці та інші дослідження лише частково заповнюють ту прогалину, яка залишається в сфері вивчення періодики українського закордоння, адже більшість періодичних видань, які з’являлися поза Україною (від «Арки» - до «Хорса»), частково чи повністю залишаються для нас «загадками», примірники багатьох із них і досі припадають пилом в архівах чи бібліотеках Києва, Мюнхена чи Нью-Йорка в очікуванні на свого дослідника-рятівника. Однією з таких малознаних сторінок в історії української журналістики є існування на південноамериканській землі часопису «Пороги».

Зацікавлення «Порогами» посилюється тим, що публікацій, присвячених цьому виданню, на жаль, дуже мало. Важливим джерелом до його вивчення поки що є не наукові дослідження, а спогади тих, хто працював у редакції часопису або брав безпосередню участь у культурному житті української еміграції в Аргентині. Насамперед це стосується відомого письменника Ігора Качуровського, чиї мемуари «Ми - в Аргентині» [6] проливають світло як на досі маловідомі сторінки 3 культурного, зокрема й видавничого життя українців у цій країні після Другої світової війни загалом, так і розкривають подробиці з історії творення часопису «Пороги». І. Качуровський розповідає про початки існування редакції часопису, його відповідальних редакторів, авторів, подає цікаві відомості з життя творчої інтелігенції української громади, яка перебувала після Другої світової війни в Аргентині і брала найбезпосереднішу участь у видаванні часопису.

Одним із найвагоміших джерел у вивченні історії та змісту журналу і нині залишаються матеріали, зокрема рубрики «Від редакції», які побачили світ на сторінках «Порогів» у 1940-1950-ті рр. Цінність таких публікацій насамперед у тому, що завдяки важливим подробицям 3 редакційного життя, датам, іменам редакторів і видавців, відомості 
про які вони містять, саме ці публікації є найточнішими джерелами, так би мовити інформацією з перших уст, до створення детальної історії та опису змісту цього часопису.

Ще одним цінним джерелом, який має посприяти науковому вивченню «Порогів», є хронологічний та систематичний покажчики змісту цього часопису, який нещодавно підготовлено автором цих рядків [7].

\section{Мета й завдання статmі}

Мета цієї статті - на основі результатів уперше підготовлених в історії української бібліографістики та історії української журналістики хронологічного та систематичного покажчиків змісту часопису «Пороги», а також покажчика авторів матеріалів журналу, дослідити особливості появи у світ цього видання, його зміст, хронологічні межі, кількість виданих примірників, імена, кількість та «географію» авторів, які взяли участь у його творенні, період становлення та подробиці всієї подальшої історії, тематично-жанрову класифікацію матеріалів, й таким чином, створивши «портрет» цього літературно-мистецького часопису, зберегти відомості про нього як про унікальний і важливий історико-літературний документ, який з'являвся у світ далеко від України, але плекався з думою про Україну.

\section{Виклад основного матеріалу}

Перше число «Порогів» - українського часопису у далекій від нас Аргентині - вийшло у жовтні 1949 року. Для багатьох українців, які перебували тоді в цій країні, це справді були «рідні пороги» в чужій стороні. Ті пороги рідного слова, рідної літератури, рідної культури, які наближали кожного, хто опинився на чужині, до таких незабутніх порогів отчого дому. Примітно, що на той час це був перший український часопис літературного спрямування не лише у цій південноамериканській країні, а й на всю західну півкулю (Північну та Південну Америки). Бо ж і «Нові дні» (Канада), і «Київ» (США), i «Овид»(Аргентина - США) та інші журнали з'явилися пізніше, вже після «Порогів».

Це був літературно-мистецький журнал, який виходив у світ упродовж 1949-1957 pр. Варто зауважити, що саме цей - після Другої світової війни - період позначився в Аргентині відчутним пожвавленням українського культурного життя, спричиненим прибуттям сюди із Західної Європи сотень тисяч представників нової хвилі української еміграції. На цей час, приміром,припадає початок діяльності «позапартійної й відкритої для кожного письменника, артиста, художника, вченого» Спілки, яка «відбувала свої зустрічі в самому центрі велетенського Буенос-Айреса». Численні заходи, зокрема літературного змісту, відбувалися і в «Українському клюбі». Змістовнішими стали видання «Наш клич» та «Українське слово». Неабиякою подією в житті 
громади стала також поява 1950 р. у видавництві «Полтава» (власник Дем’ян Савчук) «Кобзаря» Т. Шевченка (з іспано- та англомовними передмовами), ілюстрованого репродукціями з архіву Чоловського. Це видання, за словами Ігоря Качуровського, було прикметним ще й тим, що читач знаходив у ньому (зокрема, в поемах «Невольник» та «Неофіти») ті рядки, які в совєтських виданнях «Кобзаря» було вилучено. Ще один український друкар в Аргентині Микола Денисюк почав видавати місячник «Овид», численну книжкову продукцію.

Саме в таких-от умовах піднесення українського культурного життя наприкінці 1940-х років минулого століття й вийшло у світ перше число «Порогів». До такого кроку - видавати літературний журнал власників видавництва «Перемога» Сидора Кравця та Михайла Паренюка намовив письменник Анатоль Галан (Калиновський). I хоча на сторінках журналу зазначено, що підготовкою до друку опікувалася редакційна колегія, проте саме він, Анатоль Галан, редагував перші числа щойно заснованого часопису. Потім одне число зредагував Олекса Сацюк, а решту - Ігор Качуровський. Загалом за вісім років існування «Порогів» вийшло 77 чисел цього часопису: перше - у жовтні 1949 року, а останнє - наприкінці 1957 року. В 1949 році до читачів прийшло три числа, у 1950-1954 роки - по дванадцять, 1955 - не вийшло жодного числа, 1956 - дванадцять, 1957 - два. Журнал з'являвся переважно на 32-х сторінках (інколи - на 18-ти), одначе часто «спареними», навіть «строєними» числами, що засвідчує складність ситуації з видаванням українських часописів після Другої світової війни, незалежно від країни.

«Журнал був позапартійний, нізвідки не діставав дотацій, але все таки ми протрималися майже вісім років», - писав у спогадах «Ми в Аргентині» відомий поет і літературознавець Ігор Качуровський, який, як ми вже зазначили, брав найбезпосереднішу участь як у редагуванні часопису, так і загалом у літературному житті української громади Аргентини. Окрім згаданих редакторів, участь у творенні часопису брали й інші представники української інтелігенції (літератори, художники, скульптори, актори), осередок якої перебував на той час у столиці Аргентини і виявляв неабияку згуртованість та активність. Прикметно, що багато хто з них прибув до Південної Америки з Німеччини та Австрії, де, належачи до редакційних колегій різних видань, уже отримав досвід участі у творенні тамтешніх еміграційних газет та журналів, зокрема й літературних («Літаври», «Звено», «Керма», «Українськівісті», «Останні новини» тощо) [8]. Певне, саме цим - наявністю в Аргентині згуртованих ще під час перебування в Європі літературних кадрів - насамперед і можна пояснити той факт, що «Пороги» стали першим літературним виданням, яке вийшло в світ у країнах західної півкулі після Другої світової війни. 
Серед творчо-ідеологічних засад літературно-мистецького журналу «Пороги», про які йдеться в статті «Від видавництва» [9], зустрічаємо й такі: «уможливлення безпосередніх взаємин письменників 3 читачем», «нагадування читачам про поневолену батьківщину», «популяризація українського образотворчого мистецтва», «знайомство читача 3 кращими творами наших колег - аргентинських письменників та письменників інших країн» тощо.

За вісім років існування часопису на його сторінках видрукувано 810 матеріалів різних жанрів. Ознайомлення зі змістом цих публікацій дає підстави класифікувати їх за жанрами (або темами) у такий спосіб: «Поезія» (216 публікацій), «Проза» (96), «3 перекладів» (123), «Рецензії, відгуки» (42), «Драматургія» (11), «Від редакції» (8), «Статті, огляди: мистецтво, література, історія, інше» (39), «Імена і дати» (44), «Літературна творчість» (7), «Гумор і сатира» (47), «Бібліографія» (11), «Спогади, щоденники» (24), «Мандри» (7), «Афоризми» (1), «Новини 3 української культури: театральні постановки, музичні концерти, мистецькі виставки» (17), «Втрати» (4), «Видавнича діяльність» (5), «Науково-популярні нотатки» (14), а також «Різне» (32) та «Ілюстрації» (62). Таким чином, усі матеріали часопису можна представити в двадцяти розділах. Така класифікація має допомогти орієнтуватися в огромі різнотемних та різножанрових матеріалів усім тим, хто цікавиться набутками української еміграції в царині слова, історією преси, літератури і хто продовжуватиме дослідження змісту часопису «Пороги».

Часопис друкував поетичні твори (поезії, поеми), зокрема таких авторів: Олекси Веретенченка, Ігоря Качуровського, Діамари Комілевської (Діми), Юрія Косача, Наталі Лівицької-Холодної, Оксани Лятуринської, Галі Мазуренко, Євгена Маланюка, Бориса Олександріва, Василя Онуфрієнка, Михайла Ореста, Леоніда Полтави, Олеся Раня, Михайла Ситника, Яра Славутича, Остапа Тарнавського, Ганни Черінь та інших. Серед авторів прозових творів (оповідання, новели, уривки 3 повістей та романів) - імена Анатоля Галана, Євгена Гарана, Докії Гуменної, Зосима Дончука, Олекси Ізарського, Ігоря Качуровського, Володимира Коба (Кость Бульдин), Діамари Комілевської, Леоніда Лимана, Федора Одрача, Євгена Онацького, Софії Парфанович, Володимира Русальського, Олекси Сацюка, Юрія Тиса, Марії Цуканової, Василя Чапленка та інших [10].

Прикметно, що на сторінках цього, не зовсім «товстого», журналу (впереваж, нагадаю, друкувався на 32-х сторінках) знайшли своє місце і твори драматичного жанру, зокрема п'єси Діамари Комілевської («Пересаджені квіти»), Юрія Тиса («Святоіванська ніч»), Василя Чапленка («Чий злочин») тощо. Це також свідчить, з одного боку, про бажання творців часопису видавати журнал змістовним та читабельним, урізноманітнювати його жанрову палітру, а з другого - про ба- 
жання літераторів, які перебували на еміграції, зробити свій внесок у розвій драматичного жанру в українській літературі.

Помітне місце в часописі відведено перекладам творів світової літератури. Завдяки «Порогам» українському читачеві стали доступними твори письменників австралійської, американської, англійської, іспанської, німецької, французької, польської, білоруської, албанської та інших літератур. Зокрема, зі сторінок часопису до українського читача вперше прийшли деякі твори Джорджа Гордона Байрона, Райнера Марії Рільке, Роберта Бернса, Шарля Бодлера, Оскара Вайлда, Поля Валері, Волта Вітмена, Поля Верлена, Генріха Гайне, Фрідріха Гельдерліна, Ернеста Гемінґвея, Стефана Георге, Йоганна Вольфганга Гете, Джона Кітса, Агати Крісті, Марії Конопніцкої, Новаліса, Вільяма Шекспіра, Максіма Танка та низки інших представників чужих літератур. Така увага до іноземних мов і літератур свідчить про прагнення українських авторів наблизитися до глибин світової літератури загалом і культур тих країн, де жили українці-емігранти зокрема. Примітно, що в процесі наближення творів світової художньої літератури до українського читача на сторінках «Порогів» взяли участь такі знані майстри українського перекладу, як Михайло Орест, Володимир Державин, Оксана Драгоманова, Ігор Костецький - ті, хто перебував на чужині; також надруковано твори класиків українського перекладу Миколи Зерова та Освальда Бурггардта (Юрія Клена).

Привернуть увагу сучасного дослідника і матеріали інших розділів нашої класифікації змісту часопису, зокрема «Спогади». Адже чимало цікавих, надрукованих лише в цьому виданні мемуарів дають можливість доповнити досі незнаним або маловідомим фактажем портрети багатьох відомих осіб. Таким чином, у серії цих матеріалів ми довідуємось цікаві подробиці про Миколу Зерова (Ч. 13, 1950), Дмитра Загула (Ч. 23-24, 1951), Агатангела Кримського (Ч. 32-33, 1952), Юрія Клена (Ч. 25-27, 1951), ілюстратора «Енеїди» Василя Корнієнка (Ч. 76, 1957), а також про події періоду УНР (Ч. 61-63, 1954), а ще - віденські спогади Оксани Драгоманової (Ч. 28-29, 1952) та ін. Усі ці матеріали поряд із характеристиками відомих осіб суттєво доповнюють і картину літературно-мистецького та наукового життя українців у різні історичні періоди.

Значну увагу журнал приділяв публікаціям недрукованої спадщини українських письменників (зокрема, поезій Миколи Зерова, Юрія Клена, Олександра Олеся, Олега Ольжича, Володимира Свідзінського, Павла Филиповича), а також творам класиків української літератури (Тарас Шевченко, Іван Франко, Леся Українка та ін.), друкував і добірки радянських поетів (Павло Тичина, Максим Рильський). Усе це $\epsilon$ свідченням того, що редактори часопису і в такий спосіб - шляхом добору і публікації творів, які як за тематикою, так і за духом, були 
особливо близькими емігрантам, - ставили перед собою свідоме завдання-покликання плекати рідне слово на чужині, а відтак і намагалися видрукувати твори якомога ширшого, різного за долею і творчим темпераментом, кола авторів.

Усього на сторінках часопису надруковано твори 231 автора. Переважно це ті, хто перебував у самій Аргентині (Анатолій Галан (Калиновський), Ігор Качуровський, Марія Цуканова, Олекса Сацюк). Однак не лише. До кола тих авторів, які жили на південноамериканському континенті, активно долучалися автори з інших куточків світу, тому часопис друкував твори представників Австралії (Василь Онуфрієнко, Олекса Рань, Володимир Русальський), Великобританії (Галя Мазуренко), Німеччини (Михайло Орест, Володимир Державин), Франції (Софія Наумович, Леонід Полтава), США (Докія Гуменна, Галина Журба, Юрій Косач, Софія Парфанович, Яр Славутич), Канади (Федір Одрач, Борис Олександрів). Цікаво, що саме зі сторінок «Порогів» до нас прийшла й одна 3 найоригінальніших в українській літературі містифікацій - Хведосій Чичка, автором якої є Ігор Качуровський. Таким чином, у світ вийшло 29 випусків матеріалів розділу сатири та гумору «Parodiarium»- у «головній ролі» чи не кожного з них виступав саме Хведосій Чичка.

Окрім літераторів, свій помітний внесок у творення «Порогів» зробили представники інших видів мистецтва. Так на сторінках часопису ми знаходимо підтвердження тісної співпраці з виданням скульпторів (Костянтин Бульдин), художників (Борис Крюков, Віктор Цимбал), науковців (Євген Онацький), співаків (Анатолій Кабанців), що дало змогу значно розширити тематичне і жанрове розмаїття матеріалів видання, створити на сторінках часопису якомога повніший літопис подій, зафіксувати низку важливих фактів літературного, загалом культурного життя українців не лише в Аргентині, а й в інших країнах Південної Америки та всього світу. Окрім творів художньої літератури різних жанрів, мемуарів, спогадів, матеріалів з психології творчості, наукових розвідок тощо, часопис містить ще й вагомий інформаційний масив про події (хроніку), відомості про літературно-мистецьке життя, видавану в різних країнах світу українську періодику, діяльність українських видавництв (зокрема, «Перемога») та книжкові видання. Відтак матеріали «Порогів» - це ще й цінне біобібліографічне джерело, без якого нині не обійтися під час створення довідників, енциклопедій тощо [11-13].

\section{Висновки}

Вісім років існування часопису, сімдесят сім виданих чисел, вісімсот десять матеріалів різних жанрів, у написанні яких взяв участь двісті тридцять один автор, - усе це стало яскравим прикладом ствердження українського слова на чужині; таким чином сторінки 
«Порогів» досі залишаються одним із найцінніших джерел вивчення літературно-мистецького життя українців у Південній Америці, цікавою і неповторною сторінкою в історії української періодики, яка додає вкрай важливі деталі до більш загальної теми - історії перебування українців у світі.

Вже з огляду бодай на це, вкрай важливим є всебічне дослідження цього раритетного часопису. Першим кроком до такого вивчення $є$ хронологічний та систематичний покажчики змісту журналу «Пороги» - дуже посутній крок до наступного наукового вивчення матеріалів журналу. Бо «Пороги» - це досі малознаний український слід у Південній Америці, а також помітний слід як в історії української журналістики, так і в історії української літератури.

Нині дедалі важче мандрувати слідами еміграційної періодики. Відстань у часі, в якому вона з'являлася, фізичне вимирання її творців, часткова втрата редакційної документації, важкодоступність примірників - усе це не полегшує, а утруднює їі повноформатне опрацювання. Втім, якраз за таких умов іще важливішим $є$ продовження роботи над їі дослідженням, варто торувати шлях пошуку від часопису до часопису, від назви до назви, від автора до автора, від теми до теми. Адже це, можливо, останній шанс не втратити, а зберегти й набути. Кожен із цих часописів - це важливий документ доби, цінне джерело різноманітної інформації, що яскраво підтверджує цей феномен феномен існування української періодики за кордоном.

\section{ЛITЕРАТУРА}

1. Пригорницький Ю. Б’ють «Пороги» - сонце сходить! / Ю. Пригорницький // Літ. Україна (Київ). - 2015. - 19 берез. - Ч. 12.

2. Курдидик А. П’ять років еміграційної преси / А. Курдидик // Українські вісті. 1951. -18 січ. - Ч. 6.

3. Дзвінчук О. М. Часопис «Український Голос» (Вінніпег, Канада, 1910-1981 рр.): проблемно-тематичний та організаційний аспекти : автореф. дис. канд. наук із соц. комунікацій : 27.00.04 /Дзвінчук О. М.; Київ. нац. ун-т ім. Тараса Шевченка, Ін-т журналістики. - К., 2008, - 20 с.;

4. Кушнір Оксана. Журнал «Дукля» (Словаччина, 1953-2004 рр.): організаційний, проблемно-тематичний та жанровий аспекти : автореф. дис. канд. наук із соц. комунікацій : 27.00.04 /Кушнір О. В.; Київ. нац. ун-т ім. Тараса Шевченка, Ін-т журналістики. - К., 2008, - 20 с.;

5. Тимошик-Сударикова А. Редакційна політика паризького журналу «Тризуб»(1925-1940 рр.): автореф. дис. канд. наук із соц. комунікацій : 27.00.04 / Тимошик-Сударикова А.; Київ. нац. ун-т ім. Тараса Шевченка, Ін-т журналістики. - К., 2012, - 20 с.

6. Качуровський I. Ми - в Аргентині // Всесвіт (Київ). - 1991. - Ч. 3. - С. 213 - 219.

7. Козак С. Аргентинські запорожці: з думою про Україну / С. Козак. - К.: Літ. Україна, 2015. - 156 с. - («Часописи української діаспори»).

8. Козак С. Гортаючи пожовклі сторінки / С. Козак. - Мюнхен : Український вільний ун-т, 2002. - 26 с.

9. Від видавництва: [Про засади нового літературно-мистецького журналу] // Пороги (Буенос-Айрес). - 1949. - Ч. 1. - С. 2 обкл. 
10. Наші автори: [Список авторів часопису] // Пороги. - Ч. 1. - 1949. - С. 3 обкл.

11. 12-те число: [3 нагоди річниці видання журналу; Список публікацій часопису упродовж року] // Пороги (Буенос-Айрес) . - 1950. - Ч. 12. - С. 1-2

12. Про нашу перебудову: [До п’ятиріччя виходу в світ журналу], підпис: Редакція й адміністрація «Порогів» //Пороги. - Ч. 42-43. - 1953. - С. 1.

13. ВП. Передплатники: [Огляд п’ятирічного видавання журналу], підпис: Від редакції // Пороги. - 1953. - Ч. 46-47. - С. 3 обкл.

\section{REFERENCES}

1. Pryhornytskyi, Yu. (2015). Biut «Porohy» - sontse skhodyt! [They beat the «Porohy» the sun goes down!]. Kyiv: Literaturna Ukraina, Ch. 12 (in Ukrainian).

2. Kurdydyk, A. (1951). Piat rokiv emihratsiinoi presy [Five years of emigration press]. Ukrainski visti, Ch. 6 (in Ukrainian)

3. Dzvinchuk, O. M. (2008). Chasopys «Ukrainskyi Holos» (Vinnipeh, Kanada, 1910-1981 rr.): problemno-tematychnyi ta orhanizatsiinyi aspekty [Ukrainian Golos magazine (Winnipeg, Canada, 1910-1981 gg.): Problem-thematic and organizational aspects]. Avtoreferat kandydatskoi dysertatsii [Abstract of thesis candidate's dissertation]. Kyiv: Taras Shenchenko Kyiv National University, Institute of journalism, p. 20 (in Ukrainian).

4. Kushnir, O. (2008). Zhurnal «Duklia»: orhanizatsiinyi, problemno-tematychnyi ta zhanrovyi aspekty [Magazine «Duklia»: organizational, problem-thematic and genre aspects]. Avtoreferat kandydatskoi dysertatsii [Abstract of thesis candidate's dissertation]. Kyiv: Taras Shenchenko Kyiv National University, Institute of journalism, p. 20 (in Ukrainian).

5. Tymoshyk-Sudarykova, A. (2012). Redaktsiina polityka paryzkoho zhurnalu «Tryzub» (1925-1940 rr.) [Editorial policy of the Parisian magazine Trident (1925-1940)]. Avtoreferat kandydatskoi dysertatsii [Abstract of thesis candidate's dissertation]. Kyiv: Taras Shenchenko Kyiv National University, Institute of journalism, p. 20 (in Ukrainian).

6. Kachurovskyi, I. (1991). My - v Arhentyni [We are in Argentina]. Kyiv: Vsesvit, Ch. 3, pp. 213-219 (in Ukrainian).

7. Kozak, S. (2015). Arhentynski zaporozhtsi: z dumoiu pro Ukrainu [Argentine Cossacks: with a Duma about Ukraine]. Kyiv: Literaturna Ukraina, p. 156 (in Ukrainian).

8. Kozak, S. (2002). Hortaiuchy pozhovkli storinky [Swinging wobbly pages]. Munich: Ukrainian Free University, p. 26 (in Ukrainian).

9. Vid vydavnytstva: Pro zasady novoho literaturno-mystetskoho zhurnalu [From the publishing house: About the foundations of the new literary and artistic magazine] (1949). Buenos-Aires: Porohy, Ch. 1, pp. 2 (in Ukrainian).

10. Nashi avtory: spysok avtoriv chasopysu [Our authors: list magazine's authors] (1949). Porohy, Ch. 1, pp. 3 (in Ukrainian).

11. Z nahody richnytsi vydannia zhurnalu; Spysok publikatsii chasopysu uprodovzh roku [On the occasion of the anniversary edition of the magazine; List of publications of the magazine during the year] (1950). Buenos-Aires: Porohy, Ch. 12, pp. 1-2 (in Ukrainian).

12. Pro nashu perebudovu: do piatyrichchia vykhodu v svit zhurnalu [About our restructuring: until the fifth anniversary of the publication of the magazine] (1953). Buenos-Aires: Porohy, Ch. 42-43, pp. 1 (in Ukrainian).

13. Peredplatnyky: ohliad piatyrichnoho vydavannia zhurnalu [Subscribers: review of the five-year edition of the magazine]. (1953). Buenos-Aires: Porohy, Ch. 46-47, pp. 3 (in Ukrainian). 


\title{
MAGAZINE “POROHY” (ARGENTINA): HISTORY, CONTENT, AUTHORS
}

\author{
Kozak Serhii, \\ Aspirant \\ Kyiv National University of Culture and Arts \\ 36 Konovalets str. \\ 01601, Kyiv, Ukraine \\ e-mail: serkozak@bigmir.net
}

The article deals with the study of publication history, names of authors, literature co-workers staff thematic and genre classification of publications in the journal «Porohy» (The Rapids) - this unique historic and literary document, which used to come out in South America (Buenos-Aires, Argentina) in the middle on the XXth century. The article presents the results of chronological and systematic subject indices of content and authors of publications cations, which were analyzed for the first time in the history of Ukrainian journalism. Due to the information, presented in the article - about peculiarities of publication origin, chronological limits (1949-1957), number of issues (77), names and «geography» of authors, who took part in its creation, the process of formation and details of its history, the author managed both: to create «the portrait» of this literary publication and to retain the information about this unique and important historic and literary document, which emerged far from Ukraine, but was cherished with the thought about Ukraine.

The stress in put on the fact, that one of the most important sources for studying history and content of the journal is the materials, published on «Porohy» pages, under the rubrics «From Editorial staff» in particular. Their value is explained by the fact, that these materials give important details about editorial life dates, names of editors and publishers, which help to analyze the history of content and range of problems of this periodical. At the same time the pages of «Porohy» remain one of the most important sources of studying literary and artistic life of Ukrainians in South America, an interesting and unique source in the history of Ukrainian periodicals, which adds extremely important details to more general problem - to the history of Ukrainians' staying in the world. Eight years of the existence of this periodical, seventy-seven published issues, eight hundred and ten articles of different genres, two hundred and thirty-one author (231) - all this became a striking example of inveteracy assertion of the Ukrainian word in a strange-land.

Key words: "Porohy", journal, author, periodical, publishing house. 